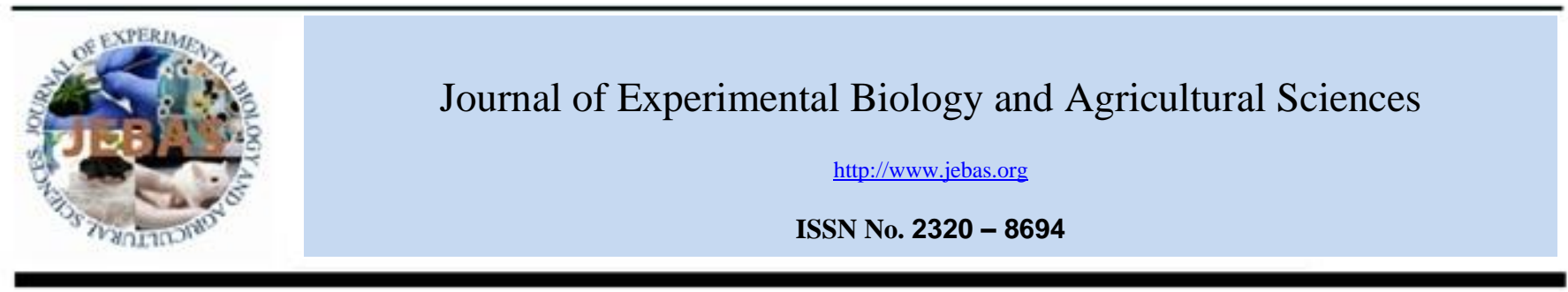

\title{
RESPONSE OF MAIZE (Zea mays L.) CROP TO BIOFERTILIZATION WITH PLANT GROWTH PROMOTING RHIZOBACTERIA AND CHITOSAN UNDER FIELD CONDITIONS
}

\section{Nadège A. AGBODJATO ${ }^{1}$, Pacôme A. NOUMAVO ${ }^{1}$, Adolphe ADJANOHOUN ${ }^{2}$, Gustave DAGBENONBAKIN $^{3}$, Mohamed ATTA ${ }^{1}$, Alejandro FALCON RODRIGUEZ ${ }^{4}$, Blanca M. de la NOVAL PONS ${ }^{4}$ and Lamine BABA-MOUSSA ${ }^{1, *}$}

\author{
${ }^{1}$ Laboratoire de Biologie et de Typage Moléculaire en Microbiologie; Département de Biochimie et de Biologie Cellulaire, Faculté des Sciences et Techniques, \\ Université d'Abomey-Calavi, Bénin \\ ${ }^{2}$ Centre de Recherches Agricoles Sud, Institut National des Recherches Agricoles du Bénin, Bénin \\ ${ }^{3}$ Centre de Recherches Agricoles d'Agonkanmey, Institut National des Recherches Agricoles du Bénin, Bénin \\ ${ }^{4}$ Departamento de Fisiologia y Bioquimica Vegetal, Instituto Nacional de Ciencias Agrícolas, MES, Cuba
}

Received - November 08, 2015; Revision - November 22, 2015; Accepted - December 20, 2015

Available Online - December 20, 2015

DOI: http://dx.doi.org/10.18006/2015.3(6).566.574

\begin{abstract}
KEYWORDS
Maize

Rhizobacteria

Chitosan

Inoculation

Biofertilization

Field
\end{abstract}

* Corresponding author

E-mail: laminesaid@yahoo.fr (Lamine BABA-MOUSSA)

Peer review under responsibility of Journal of Experimental Biology and Agricultural Sciences.

Production and Hosting by Horizon Publisher (http://publisher.jebas.org/index.html).

All rights reserved.
All the article published by Journal of Experimental Biology and Agricultural Sciences is licensed under a Creative Commons Attribution-NonCommercial 4.0 International License Based on a work at www.jebas.org.

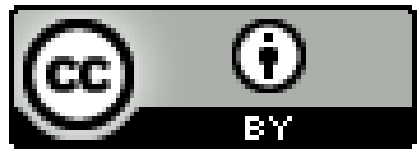




\section{Introduction}

Maize (Zea mays L.) is the most cultivated cereal in the world. It is an important crop in Southern Sahelian Africa. In Benin, it is subject to various economic transactions, and therefore represents a considerable source of incomes for producers and traders (Balogoun et al., 2013). The maize is the first consumed cereal in Benin and their productivity improvement will allow us to reach food self-sufficiency. Unfortunately, the production of maize in Benin is not spared of one of the main constraints of agriculture in Southern Sahelian Africa. This constraint is the steady decline of soil fertility that induced the reduction of crop productivity (Saïdou et al., 2012).

In order to improve the soil fertility, the producers use various mineral fertilizers, that caused several environmental and health damages. Also, the intensive use of mineral fertilizers without addition of organic matter leads to poor soil organic matter content, which is more sensitive to wind and rain erosion (Alalaoui, 2007).

To overcome the above problems, environmental advocates recommended the use of beneficial soil microorganisms and products derived from biological transformations. These products include Plant Growth Promoting Rhizobacteria (PGPR) and chitin by-product, such as chitosan.

Antoun \& Prevost (2005) affirmed that soil microorganisms having beneficial activities on plant growth and health represent an interesting and effective alternative to conventional agriculture. Plant Growth Promoting Rhizobacteria is a group of bacteria capable to actively colonize the plants root system and improve their growth and yield ( $\mathrm{Wu}$ et al., 2005). These microbes colonized all ecological niches of root at all stages of plant development, even in the presence of a competing microflora. The use of PGPRs in modern agriculture has been justified in many countries including Brazil, India, America, Argentina and Uruguay (Haghighi et al., 2011). It was well reported that these rhizobacteria are efficient to promote in vitro germination and greenhouse growth of maize (Noumavo et al., 2013).

Chitosan is a derived product from chitin and particularly extracted from the carapace of crustaceans, the insect's cuticles and the fungi walls. In agriculture, chitosan is used as a fertilizer (Lemondé et al., 2011), phytosanitary products and also used to trigger plant defense mechanisms (Le devedec, 2008). It plays an important role in the stimulation of plant growth and in mobilization of soil nutrients (Le devedec, 2008).

This study aims to assess the effects of the combination of three rhizobacteria namely $P$. fluorescens, $P$. putida and $A$. lipoferum and chitosan on the growth and seeds yield of maize under field conditions.

\section{Materials and Methods}

\subsection{Materials}

Maize seed of the EVDT 97 STR C1 variety were used for this study, this variety have 85 to 90 days development cycle (Badu-Apraku \& Yallou, 2009). Chitosan was derived from the chitin extracted from the exoskeleton of crayfish. This bioproduct was obtained from the Department of Vegetables Physiology and Biochemistry at Cuba National Institute of Agricultural Sciences (Latin America). The rhizobacterial strain used (A. lipoferum, P. fluorescens and P.putida) were isolated from the rhizosphere of maize plants in southern Benin (West Africa). These microorganisms were taxonomically isolated and characterized by Adjanohoun et al. (2011). These strains were stored at $-20^{\circ} \mathrm{C}$ in Muller Hinton broth supplemented with glycerol (10\%) at Laboratory of Biology and Microbiological Molecular Typing (University of Abomey-Calavi, Benin).

\subsection{Geographical location of experimental field}

The study was carried out in the experimental station of Southern Benin Agricultural Research Center (Figure 1) located at Niaouli in the district of Allada (Atlantic Department, Benin). It is situated at an altitude of $105^{\circ}$, longitude $2^{\circ} 19^{\prime}$ East and latitude $6^{\circ} 12^{\prime}$ North. The site is characterized by a maritime sub-equatorial climate with two rainy seasons (a great season from March to June and a small season from September to November) and two dry seasons (from July to September and from November to March). The average pluviometry is $1.200 \mathrm{~mm}$ with maximum precipitations in June and October and minimum precipitations in August. The average temperature is around $27{ }^{\circ} \mathrm{C}$. The soil is deep reddish ferrous without concretion (Aïhou, 2003).

\subsection{Chemical characteristics of the field soil}

The $\mathrm{pH}$ of 10 grams of soil suspended into $25 \mathrm{ml}$ distilled water was determined by the method described by Boudoudou (2009). The assimilable phosphorus was determined by color method at $660 \mathrm{~nm}$ (Bray \& Kurtz, 1945). The exchangeable cations $(\mathrm{Ca}, \mathrm{Mg}$ and $\mathrm{K}$ ) were determined using ammonium acetate method (Thomas, 1982). The organic carbon was evaluated by dichromate of potassium $\left(\mathrm{K}_{2} \mathrm{Cr}_{2} \mathrm{O}_{7}, 1 \mathrm{~N}\right)$ method as described by Walkley \& Black (1934).

\subsection{Preparation of experimental Field}

After clearing of soil, the plowing was done at a depth of 15 $\mathrm{cm}$ using a tractor followed by the leveling of the experimental station. Field plot of $4 \mathrm{~m} \times 3.2 \mathrm{~m}\left(12.8 \mathrm{~m}^{2}\right)$ with 4 lines of $4 \mathrm{~m}$ of long were prepared for this study. Data were collected over the useful plot $6.4 \mathrm{~m}^{2}$ consisted of the two center lines. 


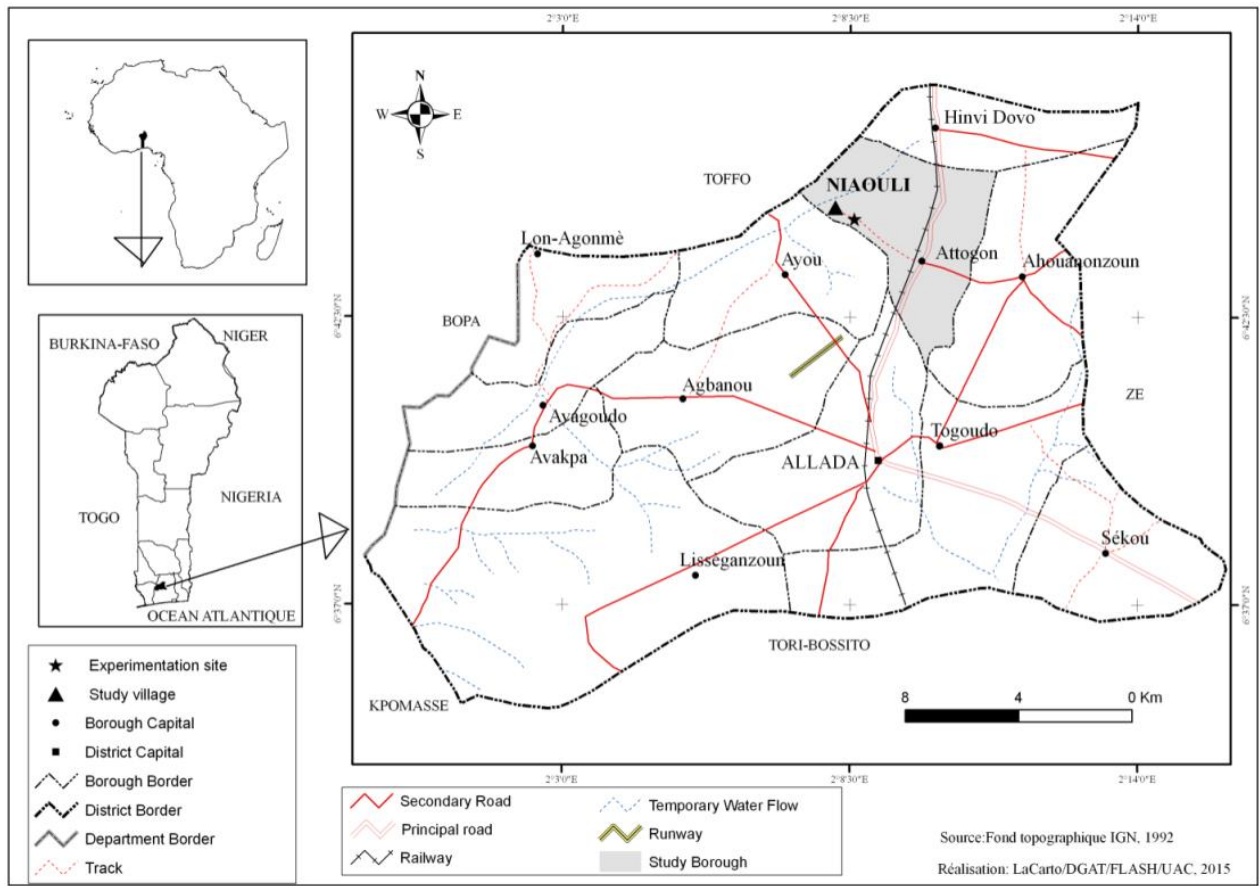

Figure 1 Geographical location of the experimental field.

\subsection{Experimental design}

The experimental design used was a Fisher block of 10 treatments with 3 repetitions. Each treatment has covered three field plots separated by an alley $(1 \mathrm{~m})$. Treatments are defined as follows: CTL: control without bacteria, chitosan, NPK (Nitrogen, Phosphorus and Potassium and Urea); Q.flu : treated both with chitosan and $P$. fluorescens; Q. put : treated both with chitosan and P. putida; Q.lip : treated both with chitosan and A. lipoferum; Q.flu-1/2npku : treated with chitosan, $P$. fluorescens and half dose of NPK and Urea; Q.put-1/2npku : treated with chitosan, P. putida and half dose of NPK and Urea; Q.lip-1/2npku : treated with chitosan, A. lipoferum and half dose of NPK and Urea; Q.flu-1npku : treated with chitosan, P. fluorescens and complete dose of NPK and Urea; Q.put-1npku: treated with chitosan, P. putida and complete dose of NPK and Urea; Q.lip-1npku : treated with chitosan, $A$. lipoferum and complete dose of NPK and Urea.

\subsection{Preparation of PGPR inoculum and chitosan solution}

After rhizobacteria revivification on agar medium, PGPR inoculum were prepared by culture on nutrient broth $(\mathrm{MH}$ broth) for $24 \mathrm{~h}$ at $30^{\circ} \mathrm{C}$ for $P$. fluorescens and $P$. putida and $37^{\circ} \mathrm{C}$ for A. lipoferum. The bacterial suspensions obtained were adjusted to $1 \times 10^{8} \mathrm{CFU} / \mathrm{ml}$ (DO 0.45 at $610 \mathrm{~nm}$ ) using the spectrophotometer (BioMATE 3S, Thermo scientific) as described by Govindappa et al. (2011). The chitosan solution was used at a concentration of $0.5 \mathrm{~g} / \mathrm{l}$.

\subsection{Sowing and inoculation of maize seeds}

A seed hole of about $5 \mathrm{~cm}$ of depth were realized and 2 maize seeds previously soaked in chitosan solution for $12 \mathrm{~h}$ were put in the hole. This procedure was immediately followed by the inoculation with $10 \mathrm{ml}$ of bacterial suspension and the seed hole has been closed immediately. Sowing was done at a distance of $0.80 \mathrm{~m} \times 0.40 \mathrm{~m}$ for a density of 31.250 plants/ha.

\subsection{Collection of growth and yield data}

The height of randomly selected 20 maize plants was measured for each treatment at the interval of every 10 days. This procedure was started from the $7^{\text {th }}$ Day After Sowing (DAS) and continued till the end of study. The height of a maize plant is the distance between the collar of plant and the last ligule leaf measured using a ruler tape. The diameter of plant was measured through the caliper. The circumference of the plants was obtained by multiplying the plant diameter by $\pi$ (to 3.14 ).

The produced biomass and maize seeds yield were evaluated at harvesting (87 DAS). The biomass of 4 plants per field hole was determined by weighing using a scale of precision (Highland HCB 302, Max: 3000 g x 0.1 g). Regarding to seeds yield, the maize cobs were harvested and shelled per plant and per field plot. Maize seeds thus obtained were dried in an oven until constant weight. They were then weighed using a scale of precision (Highland HCB 302, Max: $3000 \mathrm{~g}$ x $0.1 \mathrm{~g}$ ). The yield of maize seeds was obtained by the following formula: 


$$
\mathbf{R}=\frac{P \times 10.000}{S \times 1.000}
$$

Where: $\mathrm{R}$ is maize yield, expressed in $\mathrm{t} / \mathrm{ha}$;

$\mathrm{P}$ is the weight of maize seeds per field pot expressed in $\mathrm{kg}$.

$\mathrm{S}$ is the field pot area $\left(6.4 \mathrm{~m}^{2}\right)$

\subsection{Statistical analysis and map realization}

Comparison between treatments with regard to height, biomass, seed yielding and circumference at noose were evaluated by means of analysis of variance (AOVA) at probability level of $5 \%$ followed by Student Newman and Keuls (SNK) test. Before that, the assumptions for AOVA (normal distribution of population and equality of their variance) were examined for each variable. Only these conditions were violated for circumference at noose. For that reason, data were natural $\log$ transformed and then met the assumption. Then, analyses of variance followed by Student Newman and Keuls (SNK) test were performed on data with R statistical software 3.03. Further, in order to identify the treatments which have the highest performance for all parameters combined together, a canonical discriminate analysis was performed on the same data matrix. The geographical map of experimental field was realized using the ArcMap software version 9.2.

\section{Results}

\subsection{Chemical characteristics of the experimental field soil}

Results of chemical characterization of the experimental area field soil were revealed that the soil of study area is deficient to minerals and have low fertility (Table 1). The soil has an acid $\mathrm{pH}$ (water $\mathrm{pH} 5.6 ; \mathrm{KCl} \mathrm{pH} 4.9$ ) and low levels of phosphorus (9 ppm), organic carbon $(0.60 \%)$, organic matter $(1.03 \%)$ and sum of exchangeable bases ( $3.55 \mathrm{meq} / 100 \mathrm{~g})$.

3.2 Impact of combination of PGPR and chitosan on maize growth parameters

Effects of combined application of PGPRs and chitosan on growth parameters (height and circumference) of maize plants at $87^{\text {th }}$ DAS are summarized in Table 2 . The results of analysis of variance revealed a significance difference $(\mathrm{P}$-value $<0.05)$ between treatments for height and circumference parameters. For the height, Student Newman and Keuls test revealed that the treatment Q.put-1/2npku (chitosan, P. putida and half dose of NPK and Urea) has showed high performance $(165.17 \mathrm{~cm})$ while the treatment Q.lip (combination of chitosan and $A$. lipoferum) and Q.lip-1/2npku (the combination of chitosan, $A$. lipoferum and half dose of NPK and Urea) showed the lowest values $(139.21 \mathrm{~cm}, 140.40 \mathrm{~cm}$ respectively) without being significantly difference. Furthermore, it was reported that the treatment containing Q.put-1/2npku (combination of chitosan- $P$. putida -half dose of NPK and Urea) was followed by the Q.flu-1/2npku (combination of chitosan- $P$. fluorescens - half dose of NPK and Urea) with respective increases of $10.85 \%$ and $9.03 \%$ compared to control plants. It was also reported that the treatment Q.flu (combination of chitosan - P. fluorescens) is not significant in the improvement of plant growth while the Q. put (combination of chitosan - P. putida) improved the plant height $(3.71 \%)$ compared to control plants. The addition of NPK and Urea is important to increase the effects of these rhizobacteria and chitosan.

Regarding to circumference, there was significant difference (P-value $<0.05$ ) between the natural logs of the mean value of each treatment. The large circumferences of maize plants were induced by the Q.put-1/2npku with increase of $22.05 \%$ compared to control plants (Table 2). The combination of Q. put increased the plant circumference growth of $9.20 \%$. This increase is $22.05 \%$ inferior to than the circumference obtained from the Q.put-1/2npku. Although these results showed the importance of NPK and Urea application, further combination of chitosan and PGPR reduced the dependence of this crop on the NPK and Urea.

3.3 Impact of combination of PGPR and chitosan on biomass production and seeds yield of maize

The results of analysis of variance revealed a highly significant difference (P-value $<0.01)$ on biomass production and seed yield parameters (P-value $<0.05)$. The influence of PGPR and chitosan on the biomass production by maize plants is presented in Table 3. All treatments improved the biomass production. The combination of chitosan with PGPR has induced a better biomass production. Biomass values obtained with the plants treated with PGPR and chitosan are significantly greater than that obtained with the control plants. The largest biomass production was reported from the treatment Q.flu-1npku and it was followed by Q.flu-1/2npku. Both treatments induced $71.43 \%$ and $62.19 \%$ increases as compared to control. Except to P. putida, the combination of chitosan, rhizobacteria and NPK-Urea is better than the combination without NPK-Urea for maize biomass production.

Table 1 Chemical characteristics of the experimental field soil.

\begin{tabular}{|c|c|c|c|c|c|c|c|c|c|}
\hline \multirow[t]{2}{*}{ Sample } & \multicolumn{2}{|c|}{ pH } & \multirow{2}{*}{$\begin{array}{c}\text { Phosphorus } \\
\text { Assimilable (ppm) }\end{array}$} & \multirow{2}{*}{$\begin{array}{c}\text { Organic } \\
\text { Carbon (\%) }\end{array}$} & \multirow{2}{*}{$\begin{array}{c}\text { Organic } \\
\text { Matter (\%) }\end{array}$} & \multicolumn{4}{|c|}{ Exchangeable Bases (meq/100g) } \\
\hline & Water & $\mathrm{KCl}$ & & & & $\mathbf{K}$ & $\mathbf{C a}$ & Mg & $\mathbf{N a}$ \\
\hline Soil & 5.6 & 4.9 & 9 & 0.60 & 1.03 & 0.14 & 2.59 & 0.59 & 0.23 \\
\hline
\end{tabular}

ppm : parts per million ; meq : milliequivalents 
Table 2 Effects of combination of PGPR and chitosan on Height and Circumference of maize plants at $87^{\text {th }}$ DAS.

\begin{tabular}{|c|c|c|c|c|}
\hline \multirow[t]{2}{*}{ Treatments } & \multicolumn{2}{|c|}{ Height (cm) } & \multicolumn{2}{|c|}{ Circumference (cm) } \\
\hline & Mean & Stderr. & Mean & Stderr. \\
\hline CTL & $149.00^{\mathrm{ab}}$ & 6.21 & $4.67^{\mathrm{b}}$ & 0.11 \\
\hline Q.flu & $146.91^{\mathrm{ab}}$ & 6.52 & $4.74^{\mathrm{ab}}$ & 0.10 \\
\hline Q. put & $154.53^{\mathrm{ab}}$ & 5.18 & $5.10^{\mathrm{ab}}$ & 0.24 \\
\hline Q.lip & $139.21^{\mathrm{b}}$ & 4.59 & $4.75^{\mathrm{ab}}$ & 0.13 \\
\hline Q.flu-1/2npku & $162.45^{\mathrm{ab}}$ & 3.91 & $5.28^{\mathrm{ab}}$ & 0.34 \\
\hline Q.put-1/2npku & $165.17^{\mathrm{a}}$ & 3.61 & $5.70^{\mathrm{a}}$ & 0.19 \\
\hline Q.lip-1/2npku & $140.40^{\mathrm{b}}$ & 6.96 & $4.65^{\mathrm{ab}}$ & 0.13 \\
\hline Q.flu-1npku & $145.02^{\mathrm{ab}}$ & 4.34 & $4.87^{\mathrm{ab}}$ & 0.16 \\
\hline Q.put-1npku & $153.20^{\mathrm{ab}}$ & 3.98 & $4.92^{\mathrm{ab}}$ & 0.17 \\
\hline Q.lip-1npku & $148.74^{\mathrm{ab}}$ & 2.62 & $4.88^{\mathrm{ab}}$ & 0.30 \\
\hline F-value & 2.96 & - & 2.53 & - \\
\hline P-value & 0.021 & - & 0.040 & - \\
\hline Signification & & & & \\
\hline
\end{tabular}

$*=\mathrm{p}<0.05$ (significant); std err: standard error; In a column, the means with different letters are significantly different with probability level of $5 \%$ according to Student Newman-Keuls test; CTL: Control without bacteria, chitosan, NPK (Nitrogen, Phosphorus and Potassium and Urea); Q.flu: treated both with chitosan and P. fluorescens; Q. put: treated both with chitosan and P. putida; Q.lip: treated both with chitosan and A. lipoferum; Q.flu-1/2npku: treated with chitosan, $P$. fluorescens and half dose of NPK and Urea; Q.put1/2npku: treated with chitosan, $P$. putida and half dose of NPK and Urea; Q.lip- $1 / 2 \mathbf{n p k u}$ : treated with chitosan, A. lipoferum and half dose of NPK and Urea; Q.flu-1npku: treated with chitosan, $P$. fluorescens and complete dose of NPK and Urea; Q.put-1npku: treated with chitosan, . putida and complete dose of NPK and Urea; Q.lip-1npku: treated with chitosan, A. lipoferum and complete dose of NPK and Urea.

All treatments improved the maize seeds yield. The maize seeds yields obtained with plants treated with the combination of chitosan and PGPR were better than those obtained with control plants (Table 3). The largest yields of maize seeds (4.28 t/ha) were obtained with the plants treated with the combination of Q.put-1/2npku followed by Q.put-1npku with the increases of $44.10 \%$ and $38.38 \%$ compared to control.

\subsection{Canonical discriminant analysis of data}

The canonical discriminant analysis performed on the same data matrix showed the first two canonical axes explained $45.92 \%$ of the total variance (Figure 2 ) which is enough for a kind interpretation of results. Axis one is axis of height and axis 2 is axis of biomass. The treatment Q.put-1/2npku, Q.flu$1 / 2 \mathrm{npku}$ and $\mathrm{Q}$. put produced the highest performance for both growth and yielding parameters combined together.

\section{Discussion}

This study assessing the effects of chitosan and rhizobacteria (PGPR) on growth and yield of maize under field conditions, result of study revealed the significant impact of these two on the growth and yield of maize crop and reduced the dependency of this crop on NPK and Urea. The study area soil has acidic nature (water $\mathrm{pH} 5.6 ; \mathrm{KCl} \mathrm{pH} \mathrm{4.9).} \mathrm{Indeed,} \mathrm{the} \mathrm{soil}$ is neutral when their pH included of 6.5 to 7.5 (Baize, 2000). The water $\mathrm{pH}$ is a parameter used to assess the current soil acidity. It is not very stable over time while the $\mathrm{KCl} \mathrm{pH}$ (more stable) allows to evaluate the potential acidity of soil.
According to Bray \& Kurtz (1945) the phosphorus assimilable rate $(9 \mathrm{ppm})$ is close to the critical threshold (between 8 and 10 $\mathrm{ppm}$ ) and reveals the lower fertility of soil because it is inferior to $40 \mathrm{ppm}$. Furthermore, the soil content of organic carbon and organic matter is low. The sum of exchangeable bases (3.55 $\mathrm{meq} / 100 \mathrm{~g}$ ) is also low and less than the average level (5mol/kg) according to Malouhi (1997). In general, the field soil has low levels of minerals, hence its very low fertility level.

The effects of PGPR and chitosan on height and circumference parameters of maize plants at $87^{\text {th }}$ DAS are presented in Table 2. Note that the improvement of maize growth parameters by PGPR and chitosan varied from one treatment to another. The difference of effects observed between the treatments was significant $(p<0.05)$. Similar type of results was obtained by various researchers when they tried PGPR on various crops (Glick, 1995; Welbaum et al., 2004; Pirlak et al., 2007; Dursun et al., 2008; Jelin et al., 2013). According to Jelin et al. (2013) application of Pseudomonas strain in maize crop improved $17 \%$ plant height. Findings of these researchers are in agreement with the findings of present study where at par plant growth was reported. Similarly, Pirlak et al. (2007) reported that the inoculation of Pseudomonas BA-8 and Bacillus OSU142 strains to the apple (Mallus pumilla) trees have greatly improved the length and diameter of apple stern compared to control. Furthermore, Dursun et al. (2008) showed that Pseudomonas BA-8 and Bacillus OSU-142 have great potential to increase the growth parameters of rocket (Eruca sativa) plants. 


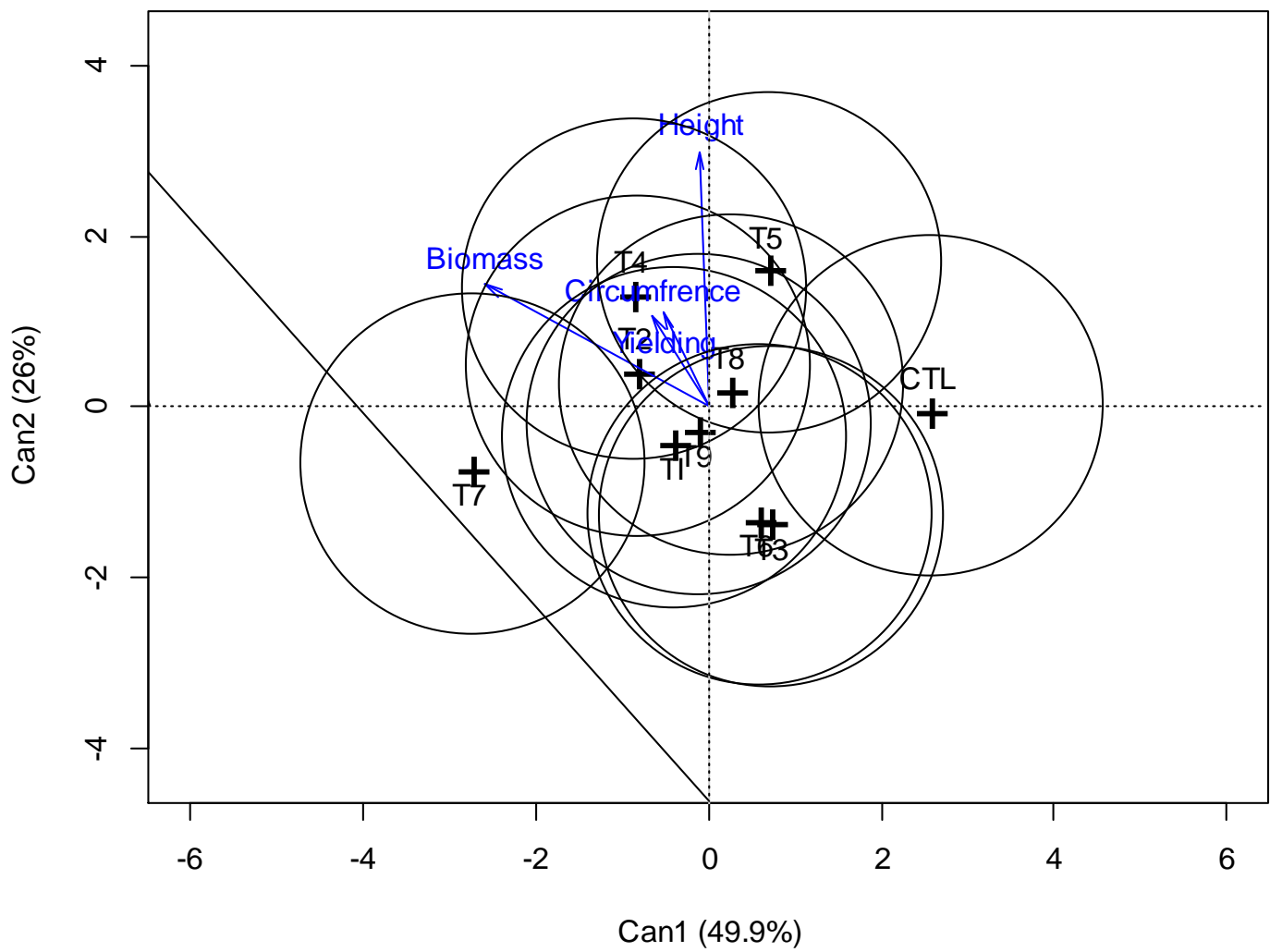

Figure 2 Plot of the two canonical discriminant functions (Can 1 and 2) based on both growth and yielding parameters.

[CTL: Control without bacteria, chitosan, NPK (Nitrogen, Phosphorus and Potassium and Urea); T1: treated both with chitosan and $P$. fluorescens; T2: treated both with chitosan and P. putida; T3: treated both with chitosan and A. lipoferum; T4: treated with chitosan, $P$. fluorescens and half dose of NPK and Urea; T5: treated with chitosan, P. putida and half dose of NPK and Urea; T6: treated with chitosan, A. lipoferum and half dose of NPK and Urea; T7: treated with chitosan, P. fluorescens and complete dose of NPK and Urea; T8: treated with chitosan, P. putida and complete dose of NPK and Urea; T9: treated with chitosan, A. lipoferum and complete dose of NPK and Urea]

The study realized by Mezaache (2012) showed that the bacterial inoculation of the tubers had induced their growth. Rajkumar et al. (2008) demonstrated that the Pseudomonas fluorescent (SE21 and RD41) applied to the red pepper (Capsicum annuиm) seeds had significantly decreased the incidence of disease caused by Rhizoctonia solani. Glick, (1995) and Welbaum et al. (2004) have mentioned the capacity of PGPR to stimulate the plant growth and their great interest for sustainable agriculture. The inoculation could compensate the deficiency in nutrients and improve the plant development through production of growth regulator stimulating root development. A large root system allows a better absorption of water and nutrients from the soil (Wu et al., 2005). Indeed, Gamalero \& Glick (2011) reported that the stimulation of plant growth by soil bacteria can also result of providing nutrients which are not sufficiently available in the soil. Several authors argue that PGPR can promote the plant growth through various mechanisms such as the nitrogen fixation $\left(\mathrm{N}_{2}\right)$ and trace elements solubilization such as phosphate $(\mathrm{P})$, inhibition of ethylene synthesis by the plant, the synthesis of plant hormones or vitamins and by decreasing the toxicity of heavy metals (Whipps, 2001; Dobbelaere et al., 2003; Cakmakci et al., 2006; Orhan et al., 2006). Noumavo et al. (2015) reported that the rhizobacteria strongly produced Indole Acetic Acid (IAA), ammonia (NH3), hydrogen cyanide ( $\mathrm{HCN})$, exopolysaccharides and exhibit strong antifungal activity against Fusarium verticillioides, real pathogen of maize.

Previously, Heinsohn \& Bjornson (1998) also reported that chitosan allows an increase of the root system growth by induction of better synthesis of growth hormone. The combination of these different PGPR and chitosan mechanisms of action explain the improvement of observed parameters' growth. The works conducted by Wanichpongpan et al. (2001) and Ramos-Garcia et al. (2009) has demonstrated the growth stimulatory effect of chitosan respectively on gerbera (Gerbera jamesonii) and gladiolus (Gladiolus spp.) plants. Hasegawa et al. (2005) obtained an increase of height and diameter of Arisaema ternatipartitum after added of chitosan in cultural substrate. Several authors have also shown the use of chitosan in stimulation of maize growth (Boonlertnirun et al., 2011; Lizarraga-Paulin et al., 2011) and cucumber (Cucumis sativus) (Shehata et al., 2012). 
Table 3 Effects of combination of PGPR and chitosan on biomass produced and yield of maize seeds at $87^{\text {th }}$ DAS.

\begin{tabular}{|c|c|c|c|c|}
\hline \multirow[t]{2}{*}{ Treatments } & \multicolumn{2}{|c|}{ Biomass (g) } & \multicolumn{2}{|c|}{ yield (t/ha) } \\
\hline & Mean & Stderr. & Mean & Stderr. \\
\hline CTL & $793.33^{c}$ & 104.14 & $2.97^{\mathrm{b}}$ & 0.26 \\
\hline Q.flu & $1100.00^{\mathrm{abc}}$ & 48.07 & $3.30^{\mathrm{ab}}$ & 0.27 \\
\hline Q. put & $1200.00^{\mathrm{ab}}$ & 48.07 & $3.50^{\mathrm{ab}}$ & 0.20 \\
\hline Q.lip & $913.33^{\mathrm{bc}}$ & 117.19 & $3.45^{\mathrm{ab}}$ & 0.38 \\
\hline Q.flu-1/2npku & $1286.67^{\mathrm{ab}}$ & 52.07 & $3.84^{\mathrm{ab}}$ & 0.27 \\
\hline Q.put-1/2npku & $1160.00^{\mathrm{abc}}$ & 62.45 & $4.28^{\mathrm{a}}$ & 0.20 \\
\hline Q.lip-1/2npku & $933.33^{b c}$ & 151.44 & $3.98^{\mathrm{ab}}$ & 0.20 \\
\hline Q.flu-1npku & $1360.00^{\mathrm{a}}$ & 69.28 & $3.65^{\mathrm{ab}}$ & 0.23 \\
\hline Q.put-1npku & $1100.00^{\mathrm{abc}}$ & 57.74 & $4.11^{\mathrm{ab}}$ & 0.28 \\
\hline Q.lip-1npku & $1060.00^{\mathrm{abc}}$ & 104.14 & $3.43^{\mathrm{ab}}$ & 0.13 \\
\hline F-value & 4.56 & - & 2.57 & - \\
\hline P-value & 0.002 & - & 0.038 & - \\
\hline Signification & \multicolumn{2}{|c|}{$* *$} & \multicolumn{2}{|c|}{$*$} \\
\hline
\end{tabular}

$*=\mathrm{p}<0.05$ (significant); $* *=\mathrm{p}<0.01$ (highly significant); std err: standard error; In a column, the means with different letters are significantly different with probability level of $5 \%$ according to Student Newman-Keuls test. All the remaining abbreviations are like table 2 .

The inoculation of maize plants by combination PGPR and chitosan has significantly improved the produced biomass in present study. The combinations of chitosan - P. fluorescenscomplete dose of NPK and Urea followed by chitosan $-P$. fluorescens- half dose of NPK and Urea have induced the best biomass production with increases of $71.43 \%$ and $62.19 \%$ compared to control (Table 3). The study conducted by Aliye et al. (2008) has shown that P. fluorescens (strains PF9 and PF20) are responsible to increase the biomass of potato plants (Solanum tuberosum). The biomass improvements obtained in present study are greater than those obtained by Adjanohoun et al. (2011). Indeed, Adjanohoun et al. (2011) have registered an increase of $59.57 \%$ of the aerial biomass, induced by rhizobacteria $P$. fluorescens. This difference is due to beneficial effects of chitosan that are added to PGPR effects. The chitosan plays then an important role in stimulation of maize plants growth.

Concerning the yields of maize seeds, the combination of chitosan - $P$. putida - half dose of NPK and Urea followed by the combination of chitosan- $P$. putida-completedose of NPK and Urea are induced the increases of $44.10 \%$ and $38.22 \%$ respectively compared to control (Table 3 ). Sundara et al. (2002) have shown that the inoculation of Bacillus megaterium solublizing phosphates allows improve the yields of sugar cane (12.6\% compared to control). Indeed, Werner (2004), affirmed that in the rhizosphere, exit very important and intensive interactions between plant, soil and microorganisms. These interactions may significantly influence the plant growth and yield at harvest. In addition, Pseudomonas BA-8 and Bacillus OSU-142 have also induced a beneficial effect on the length, crop yield and quality of fruit of pricot (Prunus armeniaca), cherry (Prunus cerasus) and raspberry (Rubus idaeus) (Esitken et al., 2005; Orhan et al., 2006). Furthermore, Asghari-Zakaria et al. (2009) found a positive effect of chitosan on the yield of potato under in vitro cultures. Chitosan has been used to stimulate the natural defenses of plants. Indeed, the chitosan spraying of vines increases the production of chitinases, the $\beta$ 1,3-glucanases (which degrade the wall of the mould) and biosynthesis of antimicrobial phenolic compounds (Amborabe et al., 2004). The combinations of chitosan, P. putida and half dose of NPK and Urea, chitosan, P. fluorescens and half dose of NPK and Urea and chitosan and $P$. putida were the treatments which produced the highest performance both for growth and yielding parameters combined together.

\section{Conclusion}

Present study brings the new knowledge's on the beneficial effects of the bioproduct chitosan in association with PGPR on growth and yield of maize in Southern Benin. Among the evaluated treatments, the combination of chitosan, P. putida and half dose of NPK-Urea improved all parameters of maize growth and yield excepted biomass produced. This treatment will allow to reduce by half the quantity of chemical fertilizers (Azote, Phosphorus, Potassium and Urea) commonly used by the farmers for maize production in Southern Benin. This new agricultural biotechnology using soil microorganisms and biological products is one of the best alternatives for a healthy and sustainable agriculture.

\section{Acknowledgements}

The authors thank the West Africa Agricultural Productivity Programme (WAAPP/PPAAO) for funding this study and the Instituto Nacional de Ciencias Agrícolas (INCA) for giving the bioproduct chitosan.

\section{Conflict of interest}

Authors would hereby like to declare that there is no conflict of interests that could possibly arise. 


\section{References}

Adjanohoun A, Baba-Moussa L, Kakai RG, Allagbe M, Yehouenou B, Gotoechanhodonou H, Sikirou R, Sessou P, Sohounhloue DCK (2011) Caractérisation des rhizobactéries potentiellement promotrices de la croissance végétative du maïs dans différents agrosystèmes du Sud-Bénin. International Journal of Biology and Chemistry Sciences 5: 433-444. doi: http://dx.doi.org/10.4314/ijbcs.v5i2.72073.

Aïhou K (2003) Interaction between organic input by Cajanus cajan and inorganic fertilization to maize in the derived savanna of the Bénin Republic. PhD Thesis submitted to the University of Abomey-Calavi, Abomey-Calavi, Benin.

Alalaoui AC (2007) Fertilisation minérale des cultures : les éléments fertilisants majeurs (Azote, Potassium et Phosphore). Bulletin Mensue ld' Information et de Liaison 155: 1-4.

Aliye N, Fininsa C, Hiskias Y (2008) Evaluation of rhizosphere bacterial antagonists for their potential to bioproject potato (Solanum tuberosum) against bacterial wilt (Ralstonia solanacearum). Biological Control 47: 282-288. doi:10.1016/j.biocontrol.2008.09.003.

Amborabe E, Aziz A, Trotel-Aziz P, Quantinet D, Dhuicq L, Vernet G (2004) Stimulation des défenses naturelles de la vigne: Essais d'emploi du chitosan contre Botrytis cinerea Phytoma. La défense des végétaux 571: 26-29.

Antoun H, Prevost D (2005) Ecology of plant growth promoting rhizobacteria. In: Siddiqui ZA (Ed). PGPR: biocontrol and biofertilization. Springer, Netherlands Pp 1-38.

Asghari-Zakaria R, Maleki-Zanjani B, Sedghi E (2009) Effect of in vitro chitosan application on growth and mini tuber yield of Solanum tuberosum L. Plant Soil and Environment 55: 252256.

Badu-Apraku B, Yallou CG (2009) Registration of StrigaResistant and Drought-Tolerant Tropical Early Maize Populations TZE-W Pop DT STR C4 and TZE-Y Pop DT STR C4. Journal of Plant Research 3: 86-90.

Baize D (2000) Guide des analyses en pédologie. INRA, Paris.

Balogoun I, Saiidou A, Ahoton LE, Adjanohoun A, Amadji G, Youl S, Mando A, Igue AM, Sinsin BA (2013) Détermination des formules d'engrais minéraux et des périodes de semis pour une meilleure production du maïs (ZeamaysL.) au Sud et au Centre Bénin. Bulletin de Recherche Agronomique du Bénin1840-7099: 1-12.

Boonlertnirun S, Suvannasara R, Promsomboon P, Boonlertnirun K (2011) Application of chitosan for reducing chemical fertilizer uses in waxy corn growing. Thai Journal of Agricultural Science 44: 22-28.
Boudoudou H, Hassikou R, OuazzaniTouhami A, Bado A, Douira A (2009) Paramètres physicochimiques et flore fongique des sols de rizières marocaines. Bulletin de la Société de Pharmacie de Bordeaux 148:17- 44.

Bray RH, Kurtz LT (1945) Determination of total, organic and available forms of phosphorus in soils. Soil Science 59: 39-45.

Cakmakci R, Donmez F, Aydin A, Sahin F (2006) Growth promotion of plants by plant growth-promoting rhizobacteria under greenhouse and two different field soil conditions. Soil Biology and Biochemisty 38: 1482-1487. doi:10.1016/j.soilbio.2005.09.019.

Dobbelaere S, Vanderleyden J, Okon Y (2003) Plant GrowthPromoting Effects of Diazotrophs in the Rhizosphere. Critical Reviews in Plant Sciences 22: 107-149. doi:10.1080/713610853.

Dursun A, Ekinci M, Donmez MF (2008) Effects of inoculation bacteria on chemical content, yield and growth in rocket (Eruca vesicaria subsp sativa). Asian Journal of Chemistry 20:3197-3202.

Esitken A, Ercisli S, Karlidag H, Sahin F (2005) Potential use of plant growth promoting rhizobacteria (PGPR) in organic apricot production. In: Libek A, Kaufmane E, Sasnauskas A (Eds.) Proceedings of the international scientific conference: Environmentally friendly fruit growing, Polli, Estonia, 7-9 September, 2005, Pp. 90-97.

Gamalero E, Glick BR (2011) Mechanisms Used by Plant Growth- Promoting Bacteria. In: Maheshwari DK (Ed.) Bacteria in Agrobiology: Plant Nutrient Management, Springer Berlin Heidelberg, Pp 17-46. doi: 10.1007/978-3-642-210617_2.

Glick BR (1995) The enhancement of plant growth by freeliving bacteria. Canadian Journal of Microbiology 41: 109117. doi: 10.1139/m95-015.

Govindappa M, Ravishankar RV, Lokesh S 2011 Screening of Pseudomonas fluorescens isolates for biological control of Macrophomina phaseolina root-rot of safflower. African Journal of Agricultural Research 6: 6256-6266. doi: 10.5897/AJAR10.1017.

Haghighi BJ, Alizadeh O, Firoozabadi AH (2011) The Role of Plant Growth Promoting Rhizobacteria (PGPR) in Sustainable Agriculture. Advances in Environmental Biology 5: 30793083.

Hasegawa A, Kanechika R, Oguni S 2005 Effect of low temperature and chitosan on dormancy breaking and growth of young corms of three Arisaema species. Acta Horticultural 673: 603-609. doi: http://dx.doi.org/10.17660/ActaHortic.2005.673.83. 
Heinsohn GE, Bjornson AS (1998) Method for treating cotyledonous plants. United States patent available on https://docs.google.com/viewer?url=patentimages.storage.goog leapis.com/pdfs/US5726123.pdf access on 25th September, 2015.

Jelin J, Selvakumar TA, Dhanarajan MS (2013) Phytological analysis for designing a microbial consortium to Enhance plant growth. International Journal of ChemTech Research 5: 13701375.

Mezaache S (2012) Localisation des déterminants de la suppression de quelques souches de Pseudomonas isolées de la rhizosphère de la pomme de terre. Thèse de doctorat, Université Ferhat ABBAS Sétif, Alger.

Le Devedec F (2008) Séparation des oligomères du chitosane par chromatographie d'affinité sur ions métalliques immobilisés. Thèse de doctorat submitted to Université du Québec, Montréal.

Lemondé M, Biasotto F, Alex S (2011) Biopolymères: chitine et chitosane, un monde à part. Chimiste 26: 9-13.

Lizarraga-Paulin EG, Torres-Pacheco I, Moreno-Martinez E, Miranda-Castro SP (2011) Chitosan application in maize (Zea mays) to counteract the effects of abiotic stress at seedling level. African Journal of Biotechnology 10: 6439-6446. doi: 10.5897/AJB10.1448.

Malouhi N (1997) Méthode d"analyses des sols. PAFPH, Cotonou.

Noumavo PA, Agbodjato NA, Gachomo EW, Salami HA, Baba-Moussa F, Adjanohoun A, Kotchoni SO, Baba-Moussa L (2015) Metabolic and biofungicidal properties of maize rhizobacteria for growth promotion and plant disease resistance. African Journal of Biotechnology 14: 811-819. doi: 10.5897/AJB2014.14132.

Noumavo PA, Kochoni E, Didagbé YO, Adjanohoun A, Allagbé M, Sikirou R, Gachomo EW, Kotchoni SO, BabaMoussa L (2013) Effect of Different Plant Growth Promoting Rhizobacteria on Maize Seed Germination and Seedling Development. American Journal of Plant Sciences. 4 : 10131021. doi:10.4236/ajps.2013.45125.

Orhan E, Esitken A, Ercisli S, Turan M, Sahin F (2006) Effects of plant growth promoting rhizobacteria (PGPR) on yield, growth and nutrient contents in organically growing raspberry. Science Horticultural111: 38-43. doi:10.1016/j.scienta.2006.09.002.

Pirlak L, Turan M, Sahin F, Esitken A (2007) Floral and Foliar Application of Plant Growth Promoting Rhizobacteria (PGPR) to Apples Increases Yield, Growth, and Nutrient Element Contents of Leaves. Journal of Sustainable Agriculture 30:145-155. DOI:10.1300/J064v30n04_11.
Rajkumar M, Lee KJ, Freitas H (2008) Effects of chitin and salicylic acid on biological control activity of Pseudomonas spp. against damping off of pepper. South African Journal of Botany 74: 268-273. doi:10.1016/j.sajb.2007.11.014.

Ramos-Garcia M, Ortega-Centeno S, Hernandez-Lauzardo AN, Alia-Tejacal I, Bosquez-Molina E, Bautista- Baños S (2009) Response of gladiolus (Gladiolus spp) plants after exposure corms to chitosan and hot water treatments. Sciences Horticultural 121: 480-484.

Saïdou A, Kossou D, Acakpo C, Richards P, Kuyper WT (2012) Effects of farmers' practices of fertilizer application and land use types on subsequent maize yield and nutrient uptake in Central Benin. International Journal of Biological and Chemical Sciences 6: 363-376.

Shehata SA, Fawzy ZF, El-Ramady HR (2012) Response of cucumber plants to foliar application of chitosan and yeast under greenhouse conditions. Australian Journal of Basic and Applied Sciences 6: 63-71.

Sundara B, NatarajanV, Hari K (2002) Influence of phosphorus solubilizing bacteria on the changes in soil available phosphorus and sugarcane yields. Field Crops Research77:43-49. doi:10.1016/S0378-4290(02)00048-5.

Thomas GW (1982) Exchangeable cations. In: Page AL, Miller RH, Keeney DR (Eds.) Methods of soil Analysis, Madison, pp. 154-157.

Walkley A, Black CA (1934) An examination of the Degtjareff method for determining soil organic matter and a proposal modification of the chromic acid titration method. Soil Science 37: 29-38.

Wanichpongpan P, Suriyachan K, Chandrkrachang S (2001) Effect of chitosan on the growth of gerbera flower plant (Gerbera jamesonii). In: Uragami T, Kurita K, Fukamizo T (Eds.) Chitin and Chitosan in Life Science, Yamaguchi.

Welbaum GE, Sturz AV, Dong Z, Nowak J (2004) Managing Soil Microorganisms to Improve Productivity of AgroEcosystems. Critical Review in Plant Science 23: 175-193. doi:10.1080/07352680490433295.

Werner D (2004) Signalling in the rhizobia legumes symbiosis. In: Varma A, Abbott L, Werner D, Hampp R (Eds.) Plant surface microbiology, Springer, New-York Pp. 99-119. doi: 10.1007/978-3-540-74051-3_6.

Whipps JM (2001) Microbial interactions and biocontrol in the rhizosphere. Journal of Experimental Botany 52(S): 487-511. doi:10.1093/jexbot/52.supp1_1.487.

Wu SC, Cao ZH, Li ZG, Cheung KC, Wong MH (2005) Effects of biofertilizer containing $\mathrm{N}$-fixer, $\mathrm{P}$ and $\mathrm{K}$ solubilizers and AM fungi on maize growth: A greenhouse trial. Geoderma 125: 155-166. doi:10.1016/j.geoderma.2004.07.003. 